\title{
Ultrasonographic Evaluation of Diseases of Hepato-biliary System in the Northern Part of Bangladesh
}

Md. Murshed Ali

CMO \& Director, Institute of Nuclear Medicine and Allied Sciences, Rangpur Medical College Campus, Rangpur 5400, Bangladesh

DOI: $10.36347 /$ sjams.2020.v08i11.027

| Received: 05.11.2020 | Accepted: 16.11.2020 | Published: 21.11.2020

*Corresponding author: Md. Murshed Ali

Abstract

Original Research Article

Introduction: Disease of gall bladder and liver are still a major problem in Bangladesh as well as in the whole World. Neoplasm of gall bladder, biliary ascariasis is more common in this region. This study was performed to evaluate the diseases of hepato-biliary system in patients attending in the Institute Nuclear Medicine and Allied Sciences, Rangpur. Methods: This retrospective study was conducted in the Centre for Nuclear Medicine and Ultrasound of Rangpur Medical College Hospital, Rangpur Bangladesh during the period from September 2017 to February 2019. A total of $1203(\mathrm{M}=578 \mathrm{~F}=625)$ patients aged from 20 years to 70 years were included in this study. Statistical data were analysed by using MS-Excel 2016. Result: A total of $1203(\mathrm{M}=578 \mathrm{~F}=625)$ patients aged from 20 years to 70 years were included in this study. In this study about 389 (32.33\%) patients were having different diseases of liver and gall bladder, among them 216 were female and 173 were male. A total of 198 patients had cholelithiasis (16.45\%). Conclusion: From this study it can be concluded that, the valuable information obtained by proper ultrasound can reduce unnecessary delay in management of diseases, thereby relieving the patient from many morbid conditions.

Keywords: Ultrasound, Hepato-biliary system, Gall bladder.

Copyright $\odot 2020$ The Author(s): This is an open-access article distributed under the terms of the Creative Commons Attribution 4.0 International License (CC BY-NC 4.0) which permits unrestricted use, distribution, and reproduction in any medium for non-commercial use provided the original author and source are credited.

\section{INTRODUCTION}

Disease of gall bladder and liver are still a major problem in Bangladesh as well as in the whole World. Among them, gall stone, liver abscess, hydatid cyst of liver, secondary neoplasm of liver, primary neoplasm of liver. Neoplasm of gall bladder, biliary ascariasis is more common in this region. Gallbladder and liver have become most common areas for evaluation with ultrasound in modern practice. Ultrasound has succeeded in maintaining its role in hepato-biliary imaging and its popularity with both patients and physicians. Availability and relative low cost make it further more attractive. No radiation is required to generate image. The examination is well tolerated, required minimal preparation and is noninvasive, painless and quick. At the same time, it is successful in visualizing the liver, gall bladder and surrounding structures in multiple planes. This retrospective study was performed to evaluate the diseases of hepato-biliary system in patients attending in the Institute Nuclear Medicine and Allied Sciences, Rangpur.

\section{Materials ANd Methods}

A total of $1203(\mathrm{M}=578 \mathrm{~F}=625)$ patients aged from 20 years to 70 years were included in this study at the Centre for Nuclear Medicine and Ultrasound, Rangpur which is located in the northern part of Bangladesh. The patients were referred from both outpatient and inpatients department of Rangpur Medical College Hospital, for ultrasound scanning of the hepatobiliary system during the period of September 2017 to February 2019. Patients had been fasting for at least 6 hours, some patients had been fasting over night. In emergency situation examination. was done without any preparation which some time makes sonography difficult but it most cases there were no problems. All images were obtained by using the $3.5 \mathrm{MHz}$ sector transducer (Sonoline SL-2, Siemen).

\section{Diagnostic Sonographic Criteria}

- Gall stone: Bright echogenic structure (s) casting acoustic shadow.

- Solid lesion: Echogenic structure with regular/irregular margin and peripheral hypoechoic halo.

- Cystic lesion: Anechoic area with definite walls with or without internal septum. 
- Liver abscess: Hypoechoic area with echogenic contents.

- Soft tissue mass in GB with stone: Solid mass with irregular /regular margin, completely/partially replacing the gall bladder with bright structure(s) casting shadow in it.

- Biliary ascariasis: Characteristic sonographic findings include visualization of worm in bile duct or gall bladder as one or more tube like structure that was either straight or coiled.

The ultrasonographic examination was carried out and sometimes second and third opinion was taken from other experts.

\section{RESULTS}

In this study total 389 (32.33\%) patients were having different diseases of liver and gall bladder, among them 216 were female and 173 were male. A total of 198 patients had cholelithiasis (16.45\%), 48 had liver abscess (3.99\%), 16 had gall stone with soft tissue mass in gall bladder $(1.33 \%), 21$ had hepatomegaly (1.74\%), 17 had uniloculated cyst $(1.41 \%) \& 12$ multiloculated cysts $(0.99 \%), 56$ had solid lesion of which $46(3.82 \%)$ had multiple lesions of various sizes in both lobe and $8(0.66 \%)$ had single lesion of liver of which $2(0.16 \%)$ had hyperechoic (haemangiomas), $3(0.24 \%)$ had soft tissue mass in gall bladder having no stones, $7(0.58 \%)$ had biliary ascariasis and 11 had biliary dilatation $(0.91 \%)$.

Table-1: Table showing age and sex distribution of sample

\begin{tabular}{|l|l|l|l|l|l|}
\hline Sex & $\mathbf{2 1 - 3 0}$ years & $\mathbf{3 1 - 4 0}$ Yr. & $\mathbf{4 1 - 5 0} \mathbf{\text { r }}$ & $\mathbf{5 1 - 6 0 Y r}$ & $\mathbf{6 0 - 7 0}$ Yr. \\
\hline Male & 82 & 149 & 152 & 103 & 92 \\
\hline Female & 97 & 153 & 157 & 113 & 105 \\
\hline Total & 179 & 302 & 309 & 216 & 197 \\
\hline
\end{tabular}

Table-2: Table showing different diseases of liver and gall bladder $(\mathrm{N}=389)$.

\begin{tabular}{|l|l|l|}
\hline Disorders & Total Number & Percentage \\
\hline Gall stone & 198 & $16.45 \%$ \\
\hline Liver Abscess & 48 & $3.99 \%$ \\
\hline Soft Tissue mass with stone in GB & 16 & $1.33 \%$ \\
\hline Hepatomegaly & 21 & $1.74 \%$ \\
\hline Multiple solid lesions & 46 & $3.82 \%$ \\
\hline Single solid lesions & 8 & $0.66 \%$ \\
\hline Hyperechoic lesions. & 2 & $0.16 \%$ \\
\hline unilocular cystic lesions. & 17 & $1.41 \%$ \\
\hline Multilocular cystic lesions. & 12 & $0.99 \%$ \\
\hline Biliary ascariasis & 7 & $0.58 \%$ \\
\hline Biliary obstruction. & 11 & $0.91 \%$ \\
\hline Soft tissue mass in GB having no stone & 3 & $0.24 \%$ \\
\hline Total & 389 & $32.33 \%$ \\
\hline
\end{tabular}

\section{DISCUSSION}

Ultrasonography has become the major diagnostic modality used for screening and evaluation of diseases of the liver and gall bladder. Gall stone can be diagnosed by ultrasonography with an accuracy of over 97\% [1]. Gallstone is still one of the most important surgical problems of the community health as well as medical and surgical emergency. There is 10$20 \%$ incidence of gallstone in adult population in western studies [2]. In this study the most common diseases are gall stone with incidence of $16.45 \%$, which also correlate with the study of Islam et al., [3] which showed that $12 \%$ of the population in Bangladesh had gall stone. Another study showed that the incidence of gall stone was $6.8 \%$ [4]. The incidence of gall stone is slightly higher in this study, most likely due to the fact that, all the patients examined had symptoms specific to gall bladder and liver diseases. Most common abnormalities identified in this study was cholelithiasis in 198 patients $(16.45 \%)$ of which 216 were female and
171 were male. The age incidence was 20 to 70 years. The study reflects higher incidence of gall stone in female patients. Ultrasonography has been shown to be extremely useful in detection and demonstration of solid and cystic lesions of the liver [5]. Among the solid lesions in liver by far the most common is secondary malignancies arising from stomach, Pancreas, colon, lung and Hodgkin's and Non-Hodgkin's lymphoma [6]. Primary neoplasm is one of the most frequent and important causes of mortality particularly in middle aged male patients [7]. Malignant neoplasm may be single or multifocal and may be high, lower or mixed echogenicity in ultrasonography [8]. Our study showed multifocal lesions in $46(3.82 \%)$ and single lesion in $8(0.66 \%)$ patients and in $2(0.16 \%)$ it showed hyperechogenic lesions (Haemangioma). Benign neoplasm in liver is rare and usually not significant except haemangioma in infant and adenoma in children and adult. In this study, 17 patients $(1.41 \%)$ were with unilocular cystic lesions and $12(0.99 \%)$ with multi locular cystic lesions in the liver. Cystic lesions in liver 
may be congenital or acquired. Congenital cystic lesion has been reported $2-5 \%$ of the population and increase in frequency with age. Cyst can be acquired by trauma or infection; among them the most common is hepatic abscess. Liver abscess is endemic in tropical countries, it may also cause hepatitis and supportive abscess [9]. In this study $48(3.99 \%)$ patients had liver abscess, some of them had undergone follow-up ultrasound scan. Ultrasound is an excellent modality for assessing the progress of liver abscess [10]. The incidence of liver abscess is also higher in this study than the study of Sadeque et al., [4] where they found $1.1 \%$ in their study population. This may be due to the fact that amebic liver abscess is common in the part of the world where sanitation is poor [11]. Gall bladder carcinoma is one of the least common GIT malignancies being preceded in frequency by colonic, pancreatic, gastric, and esophageal cancers. 67 to $98 \%$ of gall bladder cancer are associated with gall stone. In this study 30 patient had soft tissue mass in gall bladder associated with gall stone which also correlate with others studies. Biliary ascariasis is primarily common in the Indian subcontinent [12]. Adult worm live in the upper part of the small intestine and migrate to and from the bile duct through the ampulla of vater. Migration in the bile duct induce of pain in the epigastric region. ${ }^{13}$ In this study a total of 7 patients had biliary ascariasis $(0.57 \%)$. The biliary ascariasis appears more common than anticipated. The incidence of ascariasis in poor hygienic and sanitation condition is higher. This study also depicts the importance of exclusion of biliary ascariasis in patients with symptoms of liver and gall bladder disease and also the necessity of deworming routinely. Characteristic sonographic findings include visualization of worm in bile duct or gall bladder as one or more tube like structure that were either straight or coiled [14, 15]. In this study, 21 patients had hepatomegaly, most of them were suffering from jaundice. No others were noted in these patients. Both intra and extrahepatic dilatation was found in 10 patients, of which 7 were detected with choledocholithiasis and in the rest, no obvious causes was shown on the ultrasonography. Of the possible methods in practice for hepatobiliary evaluation, ultrasonography is the best for routine clinical purposes. Most clinical symptoms of hepatobiliary disorders are right upper quadrant pain which may be due to many pathological conditions (e.g. gall stone, liver abscess, neoplasm etc.). The evaluation of gall stone and hepatic focal lesions with real time ultrasonography has proven to be an extremely useful procedure [16].

\section{CONCLUSION}

From the present study it can be concluded that, the valuable information obtained by proper ultrasound can reduce unnecessary delay in management of diseases, thereby relieving the patient from many morbid conditions. There are different modalities for detection of diseases in gallbladder and liver; namely USG, radioisotope scanning, CT, MRI most agree that USG should be used as first means of study, since early CT, MRI are also sensitive but invasive, hazardous and expensive.

\section{REFERENCES}

1. Cooperberg PL, Burhenne HJ. Real-time ultrasonography: diagnostic technique of choice in calculous gallbladder disease. New England Journal of Medicine. 1980 Jun 5;302(23):1277-9.

2. Vincent LM. Biliary Ultrasound. Text book of abdominal ultrasond; Churchill living stone, New York. 1987:81-100.

3. Islam SMM, Mahmood S, Hossain GA. Prevalence of gallstone in Bangladesh population Dhaka Med J. 1997; 619: 34-36.

4. Sadeque ASQM, Islam QT, Kundu SS. Ultrasonographic evaluation of right upper quadrant abdominal pain. Bang $\mathbf{J}$ Radiology and Imaging. 1995; 3(2): 35-37.

5. Blum LL, Hasden CR, Stanberry SD. Enteric duplication cyst in children. Pediatric Radiol. 1996; 20; 326-28.

6. Kew MC. Tumour of the Liver. A Text book of Liver Diseases. Philadelphia WB, Saunders Co.1988; 1048-83.

7. Scharschmidt BF. Hepatic tumour. In Cecil Text book of Medicine. 17th Edt. Philadelphia. WB Saunder Co.1985; 848-51.

8. Sanders RC. Clinical Sonography, 2nd Edt. Little Brown and Company. London.1991: 230-35.

9. Laing FC, Federle MP, Jeffrey RB, Brown TW. Ultrasonic evaluation of patients with acute right upper quadrant pain. Radiology. 1981 Aug;140(2):449-55.

10. Cosgroove DO, McCready VR. Ultrasound Imaging-Liver-Spleen_Pancreas, Jaypee Brothers, Ist Indian Edition, 1990; 111-125.

11. Adam EM, Macleod MI. Invasive amebiasis. Medicine: 1987; 5:315-34.

12. Ellis BW. Hamilton Balley's Emergency Surgery. 12th edition. Butterwoth- Heinemann Ltd. Linacre House, London Hill. Oxford. 841.

13. Cuschieri A, Giles GR, Moossa AR. The Biliary Tract: Essential Surgical Practice. 3rd Edition, Butterworth Heinemann. Great Britain. 1995; 1175-1237.

14. Cerri GG, Leite GJ, Simoes JB, Correia Da Rocha DJ, Albuquerque FP, Machado MC, Magalhaes A. Ultrasonographic evaluation of ascaris in the biliary tract. Radiology. 1983 Mar;146(3):753-4.

15. Schulman A, Loxton AJ, Heydenrych JJ, Abdurahman KE. Sonographic diagnosis of biliary ascariasis. American Journal of Roentgenology. 1982 Sep 1;139(3):485-9.

16. Sandra LHA. Text book of diagnostic ultrasonography. India 3rd Ed, 1990: 326 - 327. 